\title{
Embodiment of Rights in Goods and the Concept of Chattel Paper
}

\author{
Thomas H. Jackson $\dagger$
}

In the scheme of classifying collateral under Article 9 of the Uniform Commercial Code, the concept of chattel paper plays a prominent, but poorly articulated, role. Most practitioners who deal with Article 9 are generally familiar with the definition of chattel paper contained in section 9-105(b), the core of which provides that chattel paper "means a writing or writings which evidence both a monetary obligation and a security interest in or a lease of specific goods."1 This definition appears simple, even straightforward, yet the relationship between chattel paper and rights in the underlying goods has been inexactly understood since the drafting of the Code. ${ }^{2}$

This article asserts that this incomplete understanding of the relation between chattel paper and rights in the underlying goods stems from two sources. First, academics as well as practitioners have failed to articulate precisely why, given the larger framework of secured financing, a category of collateral known as chattel paper exists. How chattel paper should be treated depends, in the first instance, on why it exists at all. Second, the imprecision in treating chattel paper as an embodiment of rights in goods $s^{3}$ is part of a larger failure to appreciate how the principle of ostensible ownership shapes and informs all of Article 9.4

† Professor of Law, Stanford University. I would like to thank Douglas Baird, Bonnie Jackson, and Robert Weisberg for their helpful comments on an earlier draft.

1 U.C.C. \& 9-105(b) (1978). Unless otherwise noted, all Code references will be to the 1978 Official Text of the Uniform Commercial Code and will be cited by section number only. For purposes of this article, these sections are identical to those of the 1972 Official Text.

- See Levie, Security Interests in Chattel Paper, 78 YALE L.J. 935, 935 (1969) ("Chattel paper financing is probably the least known major area of secured transactions law." (footnote omitted)).

3 The definition in section 9-105(b) hints at, but fails to explore, the concept of "embodiment." See Clark, Abstract Rights Versus Paper Rights under Article 9 of the Uniform Commercial Code, 84 Yale L.J. 445, 445 (1975) (calling such embodied rights "paper rights").

4 Under the principle of ostensible ownership, an owner of property who accords, through possession, apparent title in that property to someone else cannot later assert his title against an innocent third party who dealt with the apparent owner. Ostensible owner- 
This article first offers what I believe to be the principal function of chattel paper: making tangible an abstract right called an account receivable. So viewed, chattel paper furthers the Code's dominant goal of increasing the negotiability of collateral. ${ }^{5}$ The article then explores the relation between that reification of an abstract right and the opposite abstraction suggested by chattel paper's embodiment of rights in tangible goods. This relation arises out of the justification for chattel paper and is given meaning through an understanding of both general contractual expectancies and the role of ostensible ownership in a chattel security system. The article finally examines the consequences for the other provisions of, and policies underlying, Article 9 when this conception of chattel paper is implemented.

\section{The Basic Transaction: Chattel Paper Arising from the SALE OF Goods}

As an initial step in the analysis, consider a simple transaction. Industrial, a corporation located in New York, is a retail merchant of heavy industrial machinery. ${ }^{6}$ On January 1 , Industrial sells ten computerized drill presses to Manufacturer, a manufacturing corporation located in New Jersey. Each drill press has a purchase price of $\$ 10,000$. Manufacturer pays $\$ 10,000$ down and agrees to pay the remaining $\$ 90,000$, plus an interest charge, in twenty-four equal monthly installments. Industrial and Manufacturer sign an installment sales contract covering this transaction. In this installment sales contract, Manufacturer grants Industrial a security interest in the ten drill presses to secure Manufacturer's obligations to Industrial arising out of the contract. Industrial files

ship is perhaps the most enduring principle of chattel security law. See, e.g., Sturtevant v. Ballard, 9 Johns. 337, 339-44 (N.Y. Sup. Ct. 1812); Clow v. Woods, 5 Serg. \& Rawle 275, 279-80 (Pa. 1819). See also 1 G. Gilmore, Security Interests in Personal Property § 14.1, at 438-39 (1965) (discussion of history of requirement that secured party take possession of collateral). Cf. Davis v. Turner, 45 Va. (4 Gratt.) 422, 426-28 (1848) (court held that vendor's retention of personal property following an absolute sale created rebuttable presumption of fraud).

For further discussion of the principle of ostensible ownership and its application in Article 9, see Baird, Notice Filing and the Problem of Ostensible Ownership, 12 J. LEgaL STuD. 53 (1983); Baird \& Jackson, Possession and Ownership: An Examination of the Scope of Article 9, 35 Stan. L. REv. 175 (1983).

s See generally Gilmore, The Good Faith Purchase Idea and the Uniform Commercial Code: Confessions of a Repentant Draftsman, 15 GA. L. Rev. 605 (1981).

B The facts of this hypothetical are loosely based on Feldman v. First Nat'l City Bank (In re Leasing Consultants, Inc.), 486 F.2d 367 (2d Cir. 1973). The actual facts of Leasing Consultants, and the Second Circuit's opinion in the case, are discussed infra notes 66-86 and accompanying text. 
a financing statement in New Jersey against Manufacturer covering the drill presses.?

This transaction between Industrial and Manufacturer creates chattel paper: the installment sales contract is a writing that evidences, first, a monetary obligation-Manufacturer's obligation to pay Industrial the remaining purchase price plus interest on the drill presses-and, second, a security interest in specific goods-the security interest Industrial has in the ten drill presses that Manufacturer will now "own." Yet, although the transaction creates chattel paper, chattel paper is not relevant for any Article 9 purpose until it is used as collateral in a secured transaction. ${ }^{\circ}$ The only collateral in the hypothetical transaction between Industrial and Manufacturer, however, is the ten drill presses.

Chattel paper takes on a life of its own when Industrial, the seller and secured party in the transaction with Manufacturer, changes its role and decides to become a debtor in a separate transaction with yet another party. For example, Industrial may need to borrow money from Bank. Industrial may offer as security the installment sales contract arising out of the transaction between Industrial and Manufacturer. This installment sales contract is an asset of Industrial because it provides Industrial with the right to collect money from Manufacturer and, should Manufacturer default, the right to use the drill presses to ensure that it will be paid. ${ }^{10}$

When Industrial uses this installment sales contract-now chattel paper-as collateral with Bank, Bank takes over, at least

"Drill presses are not "mobile goods" within the meaning of section 9-103(3). See In re Dennis Mitchell Indus., 419 F.2d 349, 356-58 (3d Cir. 1969) (en banc). Industrial, therefore, will be required to file where the goods are located or expected to be located according to the terms of section 9-103(1)(a)-(c), (4).

- Thus, the two elements required under section 9-105(b) for the creation of chattel paper are present. Moreover, once the drill presses are delivered to Manufacturer, this writing will be indispensable, as it will be necessary for Industrial to have a security agreement signed by Manufacturer, as debtor, in order to have any security interest at all. $\$ 9$-203(1)(2). See generally Pontchartrain State Bank v. Poulson, 684 F.2d 704, 705-07 (10th Cir. 1982) (discussion of elements of \$ 9-203); In re Bollinger Corp., 614 F.2d 924, 926-27 (3d Cir. 1980) (same). This requirement of a writing may be thought of as fundamental to permitting the creation of a category of collateral such as chattel paper. Without this writing, the effort to give substantive effect to physical possession of the paper would be meaningless. Cf. U.C.C. $\$ 9-105$ (b) (1952) (defining chattel paper as "a security agreement or lease of a type which is in ordinary course of business transferred by delivery with appropriate indorsement or assignment").

- "The creation of a security interest in chattel paper requires at least three parties who take part in two consecutive transactions." Levie, supra note 2, at 936.

${ }_{10}$ Exercise of these rights is subject to the default rules of part 5 of Article 9. See, e.g., $\S \S 9-502$ to $-504(2)$. 
contingently, ${ }^{11}$ Industrial's rights under the installment sales contract. This gives Bank, in the event Industrial defaults, a right to the stream of payments that represents Manufacturer's obligation to pay Industrial. ${ }^{12}$ Should Bank take the proper steps to perfect that right, Bank will enjoy it in priority to Industrial's other creditors, including creditors of Industrial who acquire a property interest in that right after Bank. ${ }^{13}$

Because of its security interest in the chattel paper, Bank also takes over, again contingently and again up to the amount Industrial owes Bank, Industrial's contingent right to use the drill presses to satisfy Manufacturer's obligation to Industrial. This right, too, is an asset of Industrial, for it improves Industrial's prospects of being repaid in full from Manufacturer. ${ }^{14}$

To say that Bank, in taking a security interest in the chattel paper, has contingently succeeded to Industrial's rights as against Manufacturer is to say that those rights have become "embodied"

"The right is normally thought of as "contingent," with Bank succeeding to Industrial's rights only if Industrial defaults. Often, however, Manufacturer's obligation to pay Industrial is used as a primary repayment device on Industrial's obligation to repay Bank, in a form of notification financing. See $\$ \S 9-308$ comment $1,-318$; infra text following note 55 .

12 The rights Bank derives from Industrial are limited to the amount Industrial owes Bank, § 9-504(2) \& comment 3, unless it is determined that the transaction between Bank and Industrial amounted to a "sale" of the chattel paper, instead of a secured transaction involving chattel paper. See $\$$ 9-102(1)(b) \& comments 2, 4, -104(f), -504(2). See also Major's Furniture Mart v. Castle Credit Corp., 602 F.2d 538, 542-46 (3d Cir. 1979) (distinguishing between "sale" of and "security interest" in an account).

13 This states, in simplified form, the general "first in time, first in right" rule of Article 9. See, e.g., § 9-312(5). See also Jackson \& Kronman, Secured Financing and Priorities Among Creditors, 88 Yale L.J. 1143, 1161-64 (1979) (discussion of rules governing competing security interests in same property). Whether Bank will take priority over prior financers of Industrial claiming an interest in the chattel paper under a "blanket" security agreement and financing statement will depend on whether Bank perfects by filing or by taking possession of the chattel paper. See \$§ 9-304(1) (perfection by filing), -306(5) (priority rules upon repossession or return of goods), -308 (priority rules for purchasers of chattel paper who take possession); infra notes 87-105 and accompanying text.

14 Industrial's right to so use the drill presses will, if Industrial perfects its security interest in a timely fashion, take priority over the rights of Manufacturer's other creditors-secured and unsecured. See $\$ \S 9-201,-301$. Should Manufacturer file for bankruptcy, Industrial's rights would also have priority over those of Manufacturer's trustee in bankruptcy. See 11 U.S.C. § 544(a) (Supp. V 1981). This discussion assumes that Industrial has properly filed a financing statement covering the transaction. Since the drill presses will be "equipment" in Manufacturer's hands, see § 9-109(2), Industrial, as a purchase money seller, will have priority over all other secured parties if Industrial files the financing statement within 10 days of the date Manufacturer takes possession of the drill presses, $\S \S 9$ 107(a), -312(4). Since Bank will be unable to assert any greater rights against Manufacturer's other creditors than Industrial has, the remainder of the discussion assumes that Industrial's rights against Manufacturer in the drill presses are perfected. Baird \& Jackson, supra note 4, at $203 \& \mathrm{n} .85$ (discussing concept of derivative rights). 
in the chattel paper. As described, two rights appear embodied. The first is the right of Industrial to be paid by Manufacturer-a right that, in the absence of Industrial's security interest in the drill presses, would be an "account"1s or, if reflected by a note or similar piece of paper, an "instrument." trial's right to use the drill presses to ensure that Manufacturer's debt to Industrial will be paid, notwithstanding a default by Manufacturer. ${ }^{17}$

We will return to examine what result should follow under Article 9 from viewing these rights as embodied in chattel paper, but the apparent consequence is that Industrial's creditors no longer can deal with these rights as if they were not so embodied. ${ }^{18}$ Since Manufacturer's obligation to pay Industrial is evidenced by chattel paper, section 9-106 provides that it is not an account. ${ }^{10}$ In other words, a security interest in Industrial's "accounts," as defined in Article 9, would not cover Manufacturer's promise to pay Industrial. ${ }^{20}$ By the same token, a security interest in Industrial's "goods"21 or "general intangibles"22 would not appear to cover Industrial's right to use the drill presses to enforce Manufacturer's promise to pay it. ${ }^{23}$ As with an interest in goods evidenced by a

15 \& 9-106.

$16 \S 9-105(i)$.

17 There might be a third right as well: Industrial's right to retrieve the drill presses upon a mutual cancellation of the contract for sale. For a discussion of this right, see infra notes $148-49$ and accompanying text.

18 "It is therefore practically necessary . . . to say that . . . one perfects as to the goods by perfecting as to the chattel paper after the latter has been created." Clark, supra note 3, at 464 (emphasis in original).

20 Section 9-106 provides: "Account' means any right to payment for goods sold or leased or for services rendered which is not evidenced by an instrument or chattel paper, whether or not it has been earned by performance."

${ }^{20}$ Some of the problems of accounts being transformed into instruments are explored by Clark, supra note 3. Much of his discussion would also apply to the problems of embodying the right of payment in chattel paper. For a discussion of whether a security interest in accounts should remain effective despite the embodiment of an account receivable in chattel paper, see infra notes 44-47 and accompanying text.

21 §§ 9-105(h), -109.

$23 \S 9-106$.

22 The scope of, and limitation on, this conclusion are discussed infra notes 87-134 and accompanying text. I examine there the relation of a direct security interest in, for example, inventory, to an indirect security interest, through chattel paper, in specific goods leased or sold by a debtor.

The court in Feldman v. First Nat'l City Bank (In re Leasing Consultants, Inc.), 486 F.2d 367, 372 (2d Cir. 1973), noting that Article 9 generally classifies collateral "according to the nature or use of the underlying entity, rather than the character of its ownership at any given time," suggested that a debtor's rights in goods, whether future or contingent, remain "goods," and not "general intangibles," for the purposes of Article 9. 
negotiable document of title, ${ }^{24}$ the rights of Industrial as secured creditor of Manufacturer to the drill presses have been "locked up" in the chattel paper, and henceforth-at least for the duration of the life of the chattel paper-one seeking to derive a full set of rights in those drill presses from Industrial must deal with the chattel paper and not simply with the goods themselves. ${ }^{25}$

To perfect a security interest in either of these rights of Industrial against Manufacturer, therefore, Bank must perfect a security interest in the chattel paper: Bank must either take possession of the chattel paper ${ }^{26}$ or file a financing statement in New York, listing Industrial as the debtor and covering the chattel paper. ${ }^{27}$

\section{A Theoretical Perspective on the Role of Chattel Paper and the Concept of Embodiment}

The foregoing description of chattel paper, although familiar, is misleading in suggesting that chattel paper embodies two distinct rights. In the typical sales transaction that gives rise to chattel paper, such as that described above, the embodied rights-the use of Manufacturer's promise to pay Industrial as collateral in Industrial's transaction with Bank and the similar use of Industrial's security interest in Manufacturer's drill presses-are so complementary as to appear to be fundamentally the same. To understand this, one must have a sense of what a chattel-paper financer in a transaction like the one described above normally perceives his collateral to be.

24 Section 9-304 comment 2 states:

[S]o long as a negotiable document covering goods is outstanding, title to the goods is, so to say, locked up in the document and the proper way of dealing with such goods is through the document. Perfection therefore is to be made with respect to the document and, when made, automatically carries over to the goods. Any interest perfected directly in the goods while the document is outstanding (for example, a chattel mortgage type of security interest on goods in a warehouse) is subordinated to an outstanding negotiable document.

${ }^{28}$ This leaves open the issues of when these rights become embodied in chattel paper and how long that embodiment lasts. The remainder of this article is concerned with these questions.

20 See $\$ 9-305$.

${ }^{27}$ See § 9-304(1). Under section 9-103(4), financing statements covering chattel paper should be filed where the debtor is located. It should be noted that there is a substantial difference in the relative security offered by perfection by filing and perfection by possession. This is especially true if, in the case of filing, the chattel paper is not stamped to indicate that it is subject to a security interest. See $\$ 9-308$ \& comment 3 . 


\section{A. Contractual Expectancies, Paperized Rights, and Chattel Paper}

The rules of Article 9 seem premised on the belief that the chattel-paper financer is actually a financer on its debtor's accounts receivable-accounts receivable arising out of the sale or lease of goods-but is not a financer on the underlying goods themselves. ${ }^{28}$ Although we will later consider other transactions that give rise to chattel paper, in the case of a debtor who is a manufacturer or retail dealer of goods that are financed by a secured party, this assumption seems both correct as a matter of common understanding and consistent with the dominant existing rationale for secured credit. ${ }^{29}$

The person who finances on the basis of what we may generically call "accounts receivable" presumptively cares, in the first instance, about their value-their collectability. A security interest retained by a seller of goods to secure the unpaid purchase price-the account receivable-directly enhances the collectability of that account receivable by ranking the seller's ability to be paid with those of the buyer's other creditors. For this reason, it may well be a mistake in considering the function of chattel paper to disaggregate its two parts-the account receivable and the interest

28 This notion is implicit in the comment to section 9-106, which states: "A right to the payment of money is frequently buttressed by ancillary covenants to insure the preservation of collateral .... Whatever perfection is required for an assignment of the right to the payment of money will also carry these ancillary rights." Cf. Levie, supra note 2, at 936 ("dealers and retailers often find themselves in a position where the asset upon which they must raise the money necessary to conduct business is their chattel paper, i.e., somebody else's obligation to them"). The rights in the underlying goods that secure the right to the payment of money are best viewed as buttressing the payment right, thereby increasing its value. See infra text accompanying notes $29-32$.

20 Efficiency is probably the dominant explanation given in the literature today for the existence of secured credit. Although efficiency rationales come in a variety of forms (such as signaling explanations or risk-reduction explanations), the most widely developed efficiency rationale rests in principal part on an assumption that certain lenders are more likely to take security on certain kinds of assets either because of different monitoring abilities or because of specialization in financing on particular types of collateral. This suggests that people who finance on accounts receivable may have different skills from those who finance on goods.

For a discussion of the monitoring and specialization rationale for secured credit, see Jackson \& Kronman, supra note 13, at 1149-61; see also D. BAIRD \& T. JACKSON, CASES, Problems, and Materials on Security Interests in Personal Property ch. 4 (forthcoming 1983); Levmore, Monitors and Freeriders in Corporate and Commercial Settings, 92 YALE L.J. 49 (1982); Smith \& Warner, Bankruptcy, Secured Debt, and Optimal Capital Structure: Comment, 39 J. Fin. 247 (1979). For a criticism of the existing efficiency theories as insufficiently powerful to explain the form of secured financing, see Schwartz, Security Interests and Bankruptcy Priorities: A Review of Current Theories, 10 J. Legal Stud. 1 (1981). 
in goods. Instead, it may be preferable to recognize that the interest in goods is ancillary to the account receivable and simply serves to increase the value of the account.

Indeed, an Article 9 security interest is a right in goods only for a very limited purpose: it is defined by, and limited to, the securing of "payment or performance of an obligation."30 Consistent with this, a debtor can force a secured party to "dispose of the collateral under Section 9-504,"31 and the secured party must "account to the debtor for any surplus" realized upon such sale. ${ }^{32}$ Thus although a security interest is a form of a property right in goods or other collateral, it is distinct from other property interests in one respect: it is inextricably tied to an account receivable, or other payment or performance obligation, because it serves to enhance the prospects of repayment. Considered in this context, preCode decisions made a great deal of sense in refusing to allow a secured transfer of the security interest in the underlying goods apart from a transfer of the associated obligation, ${ }^{33}$ for the collectability of the obligation is directly tied to that security interest.

This distinction might suggest that Article 9 should not have created a category of collateral known as "chattel paper," but, rather, should have treated all rights to payments arising out of transactions in goods (other than those embodied in instruments) as "accounts." Yet chattel paper, like instruments, serves a role that accounts do not.

The creation of a category of collateral known as chattel paper appears to have been motivated by the perceived advantages of "paperizing" the obligation otherwise represented by an account. ${ }^{34}$ If the legal rules permit, and if the paper can be identified with a transaction, paperizing an intangible enables parties to determine rights from the paper itself. This attribute of tangibility, where legal rules governing the transfer of rights permit it to exist, is

so $§ 1-201(37)$.

31 \$ 9-505(2).

s2 $\$ 9-504(2)$.

ss See Epstein, Security Transfers by Secured Parties, 4 GA. L. REv. 527, 532-39 (1970); Note, Mortgages-Effect on Assignment without Assigning the Debt-Formalities Necessary to Transfer the Mortgagee's Title to the Mortgaged Property, 36 N.C.L. REv. 225, 226-27 (1958). This principle has been applied to cases under the U.C.C. See, e.g., In re AMSCO, Inc., 26 Bankr. 358 (Bankr. D. Conn. 1982); First Nat'l Bank v. Larson, (In re Kennedy Mortgage Co.), 17 Bankr. 957, 965-66 (Bankr. D.N.J. 1982).

st See Clark, supra note 3, at 473-79 (inadequacies and costs of holding abstract rights create pressures to reduce this sort of abstraction; the role of physical possession in inferring ownership also calls for a reduction in abstraction). The term "paperizing" comes from Professor Clark's article. Id. at 447 n.16. 
known as "negotiability." The key attribute of negotiability is that possession and an examination of the paper establish the limits of relevant information concerning ownership and thereby resolve competing claims to the rights deemed embodied in that paper. For such rules to have any meaning, however, there must not only be something to possess, but also something that can be said with some degree of assurance to embody the rights deemed embodied.

Although the potential for fraud remains, ${ }^{35}$ chattel paper meets those basic requirements ${ }^{36}$ in a way that an account, which is not based on an individualized writing, do not. ${ }^{37}$ In large part, therefore, the existence of chattel paper reflects the desire of the Code drafters to promote the negotiability of collateral. ${ }^{38}$

The advantages of paperizing an intangible are derived from giving substantive meaning to possession itself. Assume, for example, that Industrial obtains a financing commitment both from Bank and from Finance Company. Pursuant to Industrial's arrangement, eighty percent of the purchase price of each machine Industrial sells will be advanced by the institution that Industrial chooses, subject to an aggregate limit for each institution. Without a paperized category of collateral, both Bank and Finance Company would be required to file financing statements, presumably on Industrial's "accounts," in order to perfect their interests. But if Industrial wanted to obtain the financing from both Bank and Finance Company on a first-priority basis, Bank and Finance Company would have to negotiate a subordination agreement, or some other limitation of the scope of the financing statement, between the institutions, ${ }^{3 \theta}$ and the arrangment would require a method of determining, in the face of potential debtor misbehavior, which institution was financing which accounts. ${ }^{40}$

ss See infra note 42.

so See supra text accompanying note 1; supra note 8.

${ }^{37}$ An account may or may not be represented by a writing. See $\S 2-201$. Chattel paper arising from the sale of goods, however, will, because $\$ 9-203(1)$ (a) requires a nonpossessory security to be represented by a writing. Since many accounts will be represented by a writing, it is not inconceivable that the Code's paperizing principle could be extended further. See supra note 8.

ss See Clark, supra note 3, at 473-79; Gilmore, supra note 5, at 607-12; Kripke, Chattel Paper as a Negotiable Specialty Under the Uniform Commercial Code, 59 Yalk L.J. 1209, 1224-27 (1950) (should "assimilate" chattel paper to negotiable instruments); cf. 2 G. GILMORE, supra note 4, $\S 25.5$, at $666-69$ (discussion of chattel paper as "quasi-negotiable" collateral).

38 Section 9-316 provides: "Nothing in this Article prevents subordination by agreement by any person entitled to priority."

40 For example, if Industrial presented a list of accounts to Bank, Bank might have to develop a verification procedure with Finance Company to ensure that Industrial had not 
Paperizing the obligation, however, coupled with a legal rule that gives priority to the possessor of the paper obligation, ${ }^{41}$ provides a simple alternative to an otherwise complex arrangement. ${ }^{42}$ Both Bank and Finance Company can finance based on the sales contracts physically turned over to them. The institution possessing the sales contract gains priority in the account, as well as in the other rights embodied in that sales contract.

These advantages of negotiability ${ }^{43}$ stem from the ability to determine rights from possession. To the extent a chattel-paper financer is relying on a filed financing statement, however, there is no particular reason to treat-and Article 9 does not treat-the rights of such a financer differently from the rights of a financer on unembodied accounts. ${ }^{44}$ On the other hand, there is no reason why a person who finances a debtor's "accounts" should not enjoy a security interest in those accounts even after they become embodied in chattel paper.

A holder of a security interest in accounts, of course, should be trumped, if chattel paper's possession-based negotiability means anything, by a person who gives new value and takes possession of the chattel paper, just as such a person would take priority over a chattel-paper financer who has perfected simply by a filing. ${ }^{45}$ But

first peddled these accounts to Finance Company. These procedures would not only be complex, but they would also be subject to easy error by the implementing staff.

11 \$ 9-308(a). Even if Bank were to file a financing statement covering chattel paper, if a specific sales contract were delivered to Finance Company, Finance Company would still be "without knowledge" that this specific sales contract was subject to a security interest of Bank. Id.; see also § 1-201(25) (definition of "notice").

42 The effectiveness of paperizing the obligation into a unique tangible object determines the residual levels of uncertainty or possibility of debtor mishehavior. Problems of multiple originals of the sales contract provide the most obvious source of remaining difficulties.

4s Chattel paper is sometimes called a form of "quasi-negotiable" collateral. 2 G. GILMORE, supra note $4, \S 25.5$, at 666-69 (describing chattel paper, along with non-negotiable instruments and non-negotiable documents, as "quasi-negotiable collateral"); J. WHITE \& R. Summers, Handbook of the Law UNDER the Uniform Commercial Code § 25-17, at 107882 (2d ed. 1980) (discussion of "quasi-negotiable" nature of chattel paper). Here, quasinegotiability seems to refer to the possibility of filing with respect to these types of collateral. But, unlike nineteenth-century forms of what were referred to as quasi-negotiable collateral, chattel paper does not seem to be limited to notions of entrusting. See Gilmore, supra note 5, at 610. Section 9-308 expresses the limit of negotiability for chattel paper. The "extreme" negotiable collateral, such as instruments, embody all relevant information concerning prior ownership claims, and, therefore, purchasers can perfect a security interest only by taking possession. See §§ 9-105(1), -304(1), -309.

14 The advantages of section 9-308 are limited to a "purchaser of chattel paper . . . who gives new value and takes possession of it in the ordinary course of his business." (emphasis added).

45 See id. Boss, Lease Chattel Paper: Unitary Treatment of a "Special Kind of Com- 
the priority issues are, and should remain, distinct from the issues concerning the existence of a security interest. Financers on a debtor's accounts have little control over the paperizing of the accounts receivable ${ }^{46}$, and, although the attributes of negotiability may require subsequent possessors of the paperized right to prevail, these attributes do not also suggest that "accounts" should be defined so as to exclude accounts receivable embodied in chattel paper. ${ }^{47}$

\section{B. Embodiment of Rights in Goods: The Role of Ostensible Ownership}

Paperizing an account receivable so as to gain the attributes of negotiability associated with physical possession may underlie the creation of chattel paper as a distinct form of collateral. Yet, once created, what should be the scope of the rights created by chattel paper? At a minimum, chattel paper can be said to "embody" the account receivable-this much follows from the justification for chattel paper.

To what extent, however, should rights to the underlying goods also be deemed to be embodied in the chattel paper? We have seen, for example, that the value of an account receivable is inextricably associated with its collectability. Chattel paper, therefore, is logically defined also to include the security interest retained by a seller in the goods sold. The question, however, needs to be focused more precisely. Is chattel paper arising from the lease of goods like chattel paper arising from the sale of goods? Are rights to get the goods back other than upon a default likewise embodied in the chattel paper? The answer to questions such as these clarifies the one aspect of chattel paper that has not been

mercial Specialty, 1983 Dukk L.J. 69, 105-06, seems to agree that the right to rentals arising from lease should remain an "account," but then suggests that the consequence of this would be that "financers who take possession of lease chattel paper may nevertheless have their claims defeated by competing claims to the rentals themselves." As discussed in text, however, if lease rentals were to remain "accounts," the concept of quasi-negotiability would also seem to require possession of the chattel paper to trump filing as to the accounts. This is possible, since continuation and priority are distinct issues.

48 See Clark, supra note 3, at 449-53.

47 The issue, ultimately, is whether the accounts financer should be required in the security agreement and financing statement to describe the collateral as "accounts and chattel paper" or whether subsequent parties should be required to read "accounts" as meaning "accounts and chattel paper." However the issue is resolved, the parties can adjust their behavior to the rule. The point is that defining accounts to include chattel paper is not fundamentally inconsistent with either embodiment or the concept of negotiability. 
systematically analyzed.48

This inquiry is really more one of scope than one of concept. To say that chattel paper can embody certain rights in goods is not the same thing as saying that it should. I will narrow the normative inquiry by examining the relation between the concept of embodiment and the principle of ostensible ownership. The analysis seems most usefully conducted along two different planes: the first involves examining the temporal limits on embodiment when dealing with rights in goods; the second involves examining the quantum of rights in goods that are embodied.

1. Temporal Limits on Embodiment of Rights in Goods. We have seen how a chattel-paper debtor's rights in goods give value to the account receivable now embodied in the chattel paper, thereby becoming an inseparable part of that account receivable. The reasons, however, that argued in the transaction above for chattel paper to embody some, ${ }^{48}$ if not all, of a debtor's rights to the goods also inform the contours and ultimate duration of that embodiment.

Perhaps the most fundamental principle underlying Article 9 is ostensible ownership. Possession of personal property is the best indication of ownership. When Industrial possesses goods, such as drill presses, creditors of Industrial should be able to find out about possible security interests in these drill presses by checking the Article 9 files and seeing whether any financing statements exist that cover the drill presses. ${ }^{\text {so }}$

Should Industrial retain ${ }^{\text {s1 }}$ or regain possession of the drill

48 The most exhaustive analysis, focusing on chattel paper arising out of leases, is a recent one, Boss, supra note 45. Professor Boss's article is rich in the history of assignment of true leases and in discussing the contractual interests of the two parties to the transaction, but spends little time analyzing the scope of the ostensible ownership principle and the rights of third parties, or analyzing the tie between a right to payment of money and its underlying security.

19 The quantum of Industrial's rights that should ever be embodied is discussed infra notes $102-05$ and accompanying text.

so Other interests, such as "true" leases or bailments, are not governed by Article 9. See $\$$ 1-201(21), 9-102(1). As a consequence, Industrial's creditors will only find out about some categories of property claims in Industrial's drill presses by examining the files. The problems created by this partial application of the ostensible ownership principle are explored in Baird \& Jackson, supra note 4, at 196-201.

Apart from the problems arising from the limited scope of Article 9, it is important to note that Article 9's notice filing system is not foolproof. Names change, use of collateral changes, and debtors and collateral change location. The Code attempts to accommodate these contingencies. See, e.g., \$§ 9-103(1)(d), -306(3), -401(3), -402(7). Nonetheless, each of those rules, although justifiable for risk allocation reasons, may render a given filing system incomplete.

s1 If Industrial retained possession of the drill presses until Manufacturer paid for them 
presses, it would be inconsistent with the ostensible ownership principle to hold that Bank held a perfected interest in any of Industrial's rights in the drill presses by virtue of Bank having possession of the chattel paper. ${ }^{52}$ A contrary conclusion would leave Industrial's other creditors with no external indicia, such as nonpossession by Industrial or a filing against Industrial (covering goods or chattel paper), that someone claimed interests in the goods.

In the transaction just discussed, Article 9 would not permit Bank to retain, vis-à-vis third parties, an interest in the drill presses once Industrial regained possession of them. Section 9306(5) provides that, although Bank will retain a security interest in the drill presses that is good against Industrial, it "must be perfected for protection against creditors of the transferor [Industrial] and purchasers of the returned or repossessed goods." 53 This rule provides that upon repossession (or, indeed, any other form of reacquisition) of the goods by Industrial, ${ }^{54}$ Bank must take affirma-

in full, the ostensible ownership principle would arise $a b$ initio. This issue should be resolved as it would be in the case of returned or repossessed goods. See infra notes 53-55 and accompanying text. See generally Baird \& Jackson, supra note 4 (discussion of effect of ostensible ownership on perfection and priority of security interest). This approach, however, was not followed in American State Bank v. Avco Fin. Servs., Inc., 71 Cal. App. 3d 774, 139 Cal. Rptr. 658, decision withdrawn from official reporter, 141 Cal. Rptr. 447 (1977). At issue was the effect of sham sales of motorhomes on the rights of the bank that had been assigned the fraudulent conditional sales contracts and of the dealer's floor-plan financer. Notwithstanding the dealer's retention of the vehicles in inventory, the court accorded priority to the bank, as a chattel-paper financer, on the grounds that the chattel paper gave priority in the underlying goods themselves, and that the inventory financer should bear the burden of monitoring the debtor. 139 Cal. Rptr. at 663, 665-66.

s2 See generally Baird \& Jackson, supra note 4 (discussion of ostensible ownership problems created by nonpossessory security interests).

Bs § 9-306(5)(d); see id. comment 4. The rules of section 9-306(5) are explored in 2 G. Gnmore, supra note 4, § 27.5, at 736-38; Skilton \& Dunham, Security Interests in Returned and Repossessed Goods Under Article 9 of the Uniform Commercial Code, 17 WILLAMETTE L.J. 779 (1981); Jackson \& Peters, Quest for Uncertainty: A Proposal for Flexible Resolution of Inherent Conflicts Between Article 2 and Article 9 of the Uniform Commercial Code, 87 YALE L.J. 907, 971-83 (1978); Lord, Rights of Secured Creditors in Returned and Repossessed Goods under the Uniform Commercial Code: A Study of Section 9-306(5), 15 DuQ. L. Rkv. 165 (1976-77). Sections 9-306(5)(b), -308 do give Bank a security interest that may be effective against a prior inventory financer of Industrial, even though the latter's security interest "reattaches" when the goods are returned to Industrial. This rule is analyzed infra notes $124-48$ and accompanying text.

s Section 9-306(5), which governs rights in returned or repossessed goods, does not reach the situation in which, following an installment sale, Industrial retains possession of the goods sold until final payment, and hence retains either a security interest or title. $C f$. Chartered Bank v. Chrysler Corp., 115 Cal. App. 3d 755, 171 Cal. Rptr. 748 (1981) (after sale, manufacturer held to have retained possession of goods; under § 9-203, dealer's assignment of chattel paper gave no enforceable security interest to chattel-paper financer because 
tive steps to perfect its security interest in the drill presses themselves.

By filing a financing statement covering the drill presses at the same time as it perfects its interest in the chattel paper, Bank can, of course, obviate this need to take affirmative steps after Industrial's repossession. ${ }^{.5}$ Whether Bank will be motivated to do this will depend on the risk that Industrial will repossess without prior notice to Bank. This risk, in turn, may depend in substantial part on Bank's form of chattel-paper financing. In the case of direct notification financing, Bank notifies Manufacturer to pay it directly and thereby puts Manufacturer on notice that henceforth it should treat Bank as the assignee of all of Industrial's rights in the account and its associated security interest. In that event, Bank may face no substantial risk of Industrial's repossession without Bank's knowledge, and hence it may have no particular need to file a financing statement covering Industrial's goods. In the case of nonnotification financing, however, where the risk of such repossession will, all other things being equal, be greater, Bank either will have to adjust for that risk (by advancing less on the chattel paper) or file a financing statement covering Industrial's goods.

Article 9, on first glance, appears to work adequately in the transaction we have just described, for it ties the duration of chattel paper's embodiment of rights in goods to the ostensible ownership concerns that underlie all of Article 9. Yet reflection on the nature of the chattel-paper transaction and on its relation to the ostensible ownership principle suggests several questions. First, it is not immediately clear that there would in fact be anything misleading about a legal rule that continued the concept of embodiment, notwithstanding Industrial's retention or reacquisition of the goods, at least where Bank has filed a financing statement covering "chattel paper."

debtor never had right to possession). In this instance, "embodiment" in the chattel paper of Industrial's rights to the goods "sold" seems inconsistent with the ostensible ownership principle, see supra note 51, and might run afoul of the "fraud by possession" principle, see § 2-402(2). See also Cal. Crv. Code § 3340 (West 1970); Sturtevant v. Ballard, 9 Johns. 337, 344 (N.Y. Sup. Ct. 1812) (except in special cases, a voluntary sale of goods with an agreement that allows the vendor to retain possession is "fraudulent and void" as against creditors).

ss § 9-306 comment 4; see General Elec. Credit Corp. v. McCoy (In re Frontier Mobile Home Sales, Inc.), 635 F.2d 726 (8th Cir. 1980); Citizens \& S. Factors, Inc. v. Small Business Admin., 375 So. 2d 251 (Ala. 1979). Since the goods are not mobile goods within the scope of section 9-103(3), see supra note 7, the filing would have to be made in the jurisdiction where Industrial repossessed the goods or where it kept the goods following repossession, § 9103(1). 
A notice filing system conveys the information that the legal rules prescribe it to convey. ${ }^{68}$ One learns, for example, that if a financing statement naming Industrial as debtor covers "drill presses" or "equipment and inventory" or even, perhaps, "all goods," ${ }^{87}$ subsequent creditors are forewarned that Industrial's drill presses are not available as collateral for a secured loan, at least not without a substantial risk of loss of priority to another. But the legal rule defines the scope of that financing statement and, hence, the scope of the risk. Article 9 could provide that a security interest in goods acquired through the perfection by filing of a security interest in chattel paper remains perfected notwithstanding retention or reacquisition of the goods by the debtor. There is no reason to believe that most Article 9 financers could not, or would not, accommodate to such a rule; thus, the words "chattel paper" in a financing statement would provide equal notice to them of a potential security interest in goods in the possession of the debtor as does "equipment and inventory.",ss

In discussing Article 9's notice filing system, the issue is risk allocation, and here, as elsewhere, resolution of that issue should turn on an understanding of the relative costs imposed. ${ }^{69}$ Section 9-306(5) places the risk created by the debtor's retention or reacquisition of the goods on the chattel-paper financer, who must either monitor his debtor for such events or file initially a financing

se See generally Baird, supra note 4 (functions and limitations of notice filing); Baird \& Jackson, supra note 4 (function of notice filing in informing third parties of nonpossessory interest in property).

87 The adequacy of each of these descriptions is the subject of a large body of case law. Courts, for reasons that are rarely articulated, tend to consider financing statements that simply describe the collateral in general terms, such as "all goods" or "all personal property," to be insufficient under section 9-402. See, e.g., Johnson v. First Nat'l Bank (In re Fuqua), 461 F.2d 1186, 1188 (10th Cir. 1972); In re Mansour, 29 Bankr. 114, 115 (Bankr. S.D. Fla. 1983); Davis v. Kisko (In re McKeon), 7 Bankr. 10, $12-13$ (Bankr. N.D. Fla. 1980). But see In re JCM Corp., 8 U.C.C. Rep. Serv. (Callaghan) 247, 249-50 (W.D. Mich. 1970) (Ref.) ("all tangible property" held sufficient description of collateral). The justification for a reluctance to uphold such descriptions, given the function of Article 9's notice filing system, is not self-evident. Article 9's notice filing system seems designed principally to allow creditors to stake claims to assets and to warn subsequent claimants that these assets may no longer be treated as if they were unencumbered. Baird, supra note 4, at 59-67. From this perspective, "all goods" seems essentially unambiguous.

ss The rules for filing against chattel paper are based on the location of the debtor, not on the location of the collateral. See $\S 9-103(1)$, (3). The result just discussed is seen mast easily when one would search for both the collateral and the debtor in the same jurisdiction. Even if this were not the case, a different legal rule would simply require subsequent creditors to check two different locations. Whatever costs this rule might entail, the security interests would be discoverable through external indicia.

so See Baird \& Jackson, supra note 4, at 177, 190-94. 
statement covering "goods" to deal, automatically, with that risk. ${ }^{60}$ The opposite rule would require subsequent parties to read "chattel paper" as a warning about potential interests in the underlying goods as well, to search for financing statements against the debtor covering chattel paper, and to demand other collateral-or a subordination agreement with the chattel-paper financer-in the event of finding such a financing statement.

There are, however, several decisive reasons for placing the risk on the chattel-paper financer. First, as already noted, it is not only possible but preferable to perfect security interests in chattel paper by taking possession of the chattel paper instead of by filing. ${ }^{61}$ Chattel paper exists to capture the attributes of negotiability that stem from limiting priority information to possession of the paper itself. Given the primacy of possession of the paper, chattel paper's embodiment of the debtor's interest in the underlying goods is consistent with the ostensible ownership principle only so long as the debtor is not in possession of those goods. Once the debtor is back in possession of the goods, however, a rule that validated the perfected security interests in the goods via possession of the chattel paper would create a lien on those goods that could not be discovered by simple external search. ${ }^{62}$

It would be possible, of course, to provide a different result for security interests in chattel paper perfected by the filing of a financing statement instead of by possession, but this solution would leave some advantages to taking a possessory security interest in chattel paper and some advantages to filing a financing

So See supra notes 53-55 and accompanying text.

or See supra note 27. Indeed, possession is often viewed as the preferred method of perfection; hence the rule of section 9-308. See 2 G. GLMore, supra note $4, \S 25.5$, at 667 69.

62 The debtor could, of course, tell a searcher about the chattel-paper financer. The scheme of Article 9, however, is built on the belief that, because debtors have incentives to misbehave, external indicia of rights and priorities are needed to supplement information garnered from debtors. See, e.g., Phillips, Flawed Perfection: From Possession to Filing Under Article 9 (pt. 1), 59 B.U.L. REv. 1, 35-41 (1979). This problem is not acute when the debtor is not in possession of the underlying goods. When, for example, the drill presses are in the hands of Manufacturer, if Industrial tries to persuade someone to lend it money on the basis of Industrial's rights in the drill presses, that person is on notice, by the very fact that Industrial is out of possession, that he must investigate further to find out about Industrial's purported rights in those goods. Through investigation, the party will know whether chattel paper exists and whether Industrial still holds the unlegended original. See Baird \& Jackson, supra note 4, at 179-96; see Clark, Bankers' Guide to UCC Filing Problems-Loans for Equipment Leasing, 92 BankING L.J. 222, 238-39 (1975); Note, In re Leasing Consultants, Inc.: The Double Perfection Rule for Security Assignments of True Leases, 84 YaLE L.J. 1722, 1732-33 (1975). 
statement covering chattel paper. If both actions are going to be "required" for purposes of fully perfecting an interest in the underlying goods, there seems to be no particular reason not to have the filed financing statement specify "inventory" and not "chattel paper"- the result that is reached by concluding, as section 9306(5) suggests, that chattel paper no longer embodies rights to the goods once the goods are back in the hands of the chattel-paper debtor. ${ }^{\text {B3 }}$

2. The Quantitative Question: Embodiment of Rights in Goods and the Lease Transaction. In the case of a sale of goods that generates an installment sales contract, treating the seller's resulting paper as embodying the seller's rights to the goods that secure the account receivable is a logical outgrowth of the concept of such an account receivable. That the drafters of Article 9 decided, moreover, to create a new category of collateral-chattel paper-to deal with such accounts receivable stems from their desire, by paperizing an intangible, to secure the advantages of negotiability. ${ }^{\text {os }}$ Should the embodiment of rights in goods, however, be carried over from sales to other types of transactions involving the owner of goods? Industrial, for example, may lease its goods to Manufacturer for a week or a year, with or without an option for Manufacturer to purchase or to cancel..$^{65}$ In these cases, Industrial may reacquire the goods from Manufacturer through a default of Manufacturer, through a termination of the lease by time, or by Manufacturer's exercise of a unilateral right to cancel.

To begin to consider this, it is worth exploring the famous case of In re Leasing Consultants, Inc. ${ }^{.6}$ In that case, Leasing Consul-

es Besides directness itself, this solution would avoid the uncomfortable result reached if the debtor possesses the collateral in one state and yet has its chief executive offices in another. In that event, section 9-103(1), (3), \& (4) would provide different jurisdictions for filing.

a Article 9 provides for a degree of negotiability with respect to chattel paper that is unavailable with respect to an account, since an account is "not evidenced by an indispensable writing," § 9-106 comment. The negotiability of chattel paper is provided for in section 9-308, and one of the consequences of negotiability is that perfection by possession of the chattel paper is not only possible, see $\$ 9-305$, but, because of the priority rules of section 9 308 , is the preferred method of perfecting. Distinguishing between accounts, chattel paper, and, indeed, instruments creates other problems, principally because all three of these categories of Article 9 collateral may reflect, or embody, a right to a payment of money arising out of a sale or other transaction in goods. These problems are examined in detail in Clark, supra note 3. See also supra note 43. Article 9 could reduce at least some of these conflicts by providing that a security interest in "accounts" also covered "chattel paper." See supra note 45 and accompanying text.

es Section 9-105(b) defines chattel paper so as to cover lease transactions in goods.

6* Feldman v. First Nat'l City Bank (In re Leasing Consultants, Inc.), 486 F.2d 367 (2d 
tants ("Leasing"), a New York corporation, "leased" equipment to Plastimetrix, a New Jersey corporation, filing in New Jersey, "for informational purposes only," a financing statement listing Leasing as secured party/lessor and Plastimetrix as debtor/lessee. Leasing then borrowed money from First National City Bank ("Citibank"), giving Citibank, under a "Loan and Security Agreement," "a continuing security interest in the lease(s) and the property leased." Citibank took possession of the leases and filed financing statements in New York, listing Leasing as debtor and describing the collateral covered by the financing statement as "leases and any and all rents due and to become due thereunder, including all related equipment described therein, chattel paper represented thereby, accounts receivable therewith and proceeds arising therefrom." " Thereafter, and within about two weeks of each other, Leasing and Plastimetrix both were adjudicated bankrupts under the old Bankruptcy Act of $1898 .{ }^{69}$

The issue in the case concerned Leasing's general creditors' rights against Citibank in the leases assigned to Citibank and in the equipment leased to Plastimetrix. ${ }^{70}$ The Second Circuit held ${ }^{71}$ that Citibank had properly perfected its security interest in the chattel paper and, therefore, had perfected its security interest in the rights embodied in the chattel paper.

Cir. 1973). A substantially similar dispute, involving the same parties, arose in Feldman v. First Nat'l City Bank (In re Leasing Consultants, Inc.), 368 F. Supp. 1333, 1339-40 (S.D.N.Y. 1974).

or 486 F.2d at 369 .

${ }^{68}$ Id. at 369 n.1. Under section $9-402(\mathrm{~b})$, a financing statement need only indicate the "types" of collateral it covers. Citibank argued unsuccessfully that its security interest in Leasing's rights to get the equipment back at the termination of the lease was perfected because it was a "general intangible." $486 \mathrm{~F} .2 \mathrm{~d}$ at 371-72. This argument, however, would have made sense only if Citibank's financing statement covered general intangibles. A general intangible is defined in section 9-106 as "any personal property (including things in action) other than goods, accounts, chattel paper, documents, instruments, and money."

${ }^{6}$ Pub. L. No. 55-171, ch. 541, 30 Stat. 544 (1898) (repealed prospectively, effective Oct. 1, 1979, Bankruptcy Reform Act of 1978, Pub. L. No. 95-598, 92 Stat. 2549 (codified as Title 11 of U.S.C. (Supp. V 1981))).

${ }^{70}$ There was no dispute regarding Leasing's rights against Plastimetrix's creditors, since Leasing either had the right to repossess the machines as owner (if the leases were true leases) or as perfected secured party (if the leases were security leases). The only issue was who among Leasing's creditors would enjoy the benefits of Leasing's rights.

${ }^{71} 486$ F.2d at 371-72. The opinion of the Second Circuit is somewhat cryptic and opaque. In discussing what the court "held," I am dotting some i's and crossing some t's, but I believe that the description of what the court held is fairly extractable from the opinion. The case was remanded to determine whether the leases were true leases or security leases. Id. at 323. See also Clark, supra note 62, at 235-37 (assuming that the Second Circuit's holding granted Citibank a perfected security interest in those of Leasing's rights embodied in the chattel paper). 
The troublesome issue, as the Second Circuit saw it, was the extent to which the chattel paper embodied rights in the underlying goods. According to the court, if the leases were security leases, the chattel paper would embody all of Leasing's rights in the underlying collateral, ${ }^{72}$ presumably on the ground that, since the transaction between Leasing and Plastimetrix would fundamentally constitute a "sale," all of Leasing's remaining rights in the collateral would be captured in the concept of its "security interest" in the goods.

The Second Circuit found that if the leases were true leases, however, Leasing would have two distinct rights in the underlying equipment, and only one of the two rights would be embodied in the chattel paper. ${ }^{74}$ Even though chattel paper, by definition, covers both a "monetary obligation" and a "lease of . . . goods," a true lease between Leasing and Plastimetrix, as the Second Circuit saw matters, would cover only Leasing's rights to get the equipment back during the term of the lease because of a default by Plastimetrix. ${ }^{78}$ Leasing's right to get the equipment back at the normal termination of the lease (i.e., as a result of the passage of time, and not as a result of a default) would be a reversionary right, and this reversionary right would not be a part of a "lease of .. . goods" but, rather, would be retained by Leasing outside of the lease. ${ }^{77}$ Since it would be retained independently of the lease, and since it is the lease that would constitute chattel paper, the concept of chattel paper would not embody Leasing's reversionary rights. This result was perhaps explained most clearly by Judge Weinstein, in the district court's opinion: ${ }^{78}$

In a lease transaction, the lessor owns the property. Unlike the situation where the purported lease is really a conditional sales agreement and the "lessor" holds only a security interest in the goods, the lessor in a true lease situation has a reversionary interest. . . . A reversionary interest is that residue of an estate left in the grantor, to commence in possession

72486 F.2d at 372.

78 The tests for deciding whether a lease is a "security lease" frequently look to see whether the essence of the transaction is that of a "sale." See Mooney, Personal Property Leasing: A Challenge, 36 Bus. LAw. 1605, 1610-13 (1981).

34 486 F.2d at 371-72.

73 \$ 9-105(b).

36486 F.2d at 372 .

77 Id.

78 Feldman v. First Nat'l City Bank (In re Leasing Consultants, Inc.), 351 F. Supp. 1390 (E.D.N.Y.), remanded for evidentiary hearing, 486 F.2d 367 (2d Cir. 1971). 
after the determination [sic] of some particular estate granted out by him. ${ }^{\text {9 }}$

This explanation of the result in Leasing Consultants has been attacked as being inconsistent with the definition of chattel paper. ${ }^{80}$ Yet such an argument from definition is overly formalistic. The Leasing Consultants rationale is not necessarily inconsistent with the concept of chattel paper as an embodiment of rights. ${ }^{81}$ The question to be addressed initially is one of the extent to which chattel paper embodies a lessor's rights in the goods. It is the answer to that inquiry, in turn, that provides the proper perspective from which to analyze the decision in Leasing Consultants.

The concerns involved can be seen most clearly, perhaps, by examining the case of a lease of drill presses from Industrial to Manufacturer for one week (payment by Manufacturer to come at the end of the week), with no option for Manufacturer to renew the lease or to purchase the goods. If Bank finances Industrial on the security of Industrial's "leases," Bank is essentially financing on the stream of payments Industrial is entitled to receive from its lessees. Here, as in the sale of goods, Industrial's right to get the goods back, if Manufacturer should breach during the term of the lease, affects the value of this rental obligation. The damages Industrial will be entitled to recover from Manufacturer will depend on the difference between the rental rate to Manufacturer and the

78 Id. at 1392-93 (citations omitted); see also Levie, supra note 2, at 940-41 (arguing that a perfected security interest in a lease does not encompass a security interest in the goods themselves beyond the terms of the lease).

so Note, supra note 62, at 1729-30 (concluding that the "lease . . . of goods" language of $\$$ 9-105(b) makes no sense in the case of a true lease unless it refers to the reversion).

81 A perfected security interest need not encompass all the rights hovering around a given transaction. This fact is most commonly seen in the case of true leases from the other side of the transaction, when the lessee seeks to use his rights under the lease as security. If a creditor were to take a perfected security interest in the lessee's rights under the lease and if the lessee subsequently defaulted on his rental payments, the lessor's right to get back the goods would be superior to the creditor's perfected security interest in the term of the lease. The lessee's rights in the goods are governed by the lease, and he can grant no more extensive rights to his creditor. See Baird \& Jackson, supra note 4, at 203 \& n.85 (discussing notion of derivative rights as the norm). Unlike the lessee, the true lessor has rights in the goods during the term of the lease and rights in the goods after the term of the lease. By analogy to our sales transaction, see supra notes 9-30 and accompanying text, the lessor's rights during the term of the lease are integrally tied to the transaction giving rise to the stream of payments because the right to get leased goods back on default, and thereby to relet them, affects the likelihood that the lessor will be made whole on its expected stream of rental payments. See infra notes $82-85$ and accompanying text. When a lessor grants a chattel-paper security interest in the lease, therefore, he necessarily encumbers his rights in the goods during the term of the lease, but not necessarily his rights in the goods after the term of the lease. See also Boss, supra note 45 , at 76. 
market rate of the lease for its remaining term. ${ }^{82}$ Whether or not Manufacturer is insolvent, the amount Manufacturer will owe Industrial as a result of the breach of its lease will be a function of the amount Industrial will be able to acquire by using or leasing the goods for the duration of the lease. ${ }^{8 s}$

Industrial's right to recover the goods upon Manufacturer's breach, unlike the reversion, ${ }^{84}$ appears to be an ancillary part of the rental obligation created by Manufacturer and Industrial, for it directly affects the amount Industrial is entitled to recover against Manufacturer. Since the value of this right must be subtracted from the original rental obligation of Manufacturer to determine Industrial's damage claim against Manufacturer, it also seems to be an integral part of Industrial's assignment to Bank of the "account receivable" arising from the lease transaction with Manufacturer. ${ }^{85}$

Yet, assuming Industrial and Bank intend to create a security interest not only in the lease, but also in Industrial's reversionary right to the goods, ${ }^{86}$ the fundamental Article 9 question remains: for purposes of perfection-and hence priority over third parties-should perfection of an interest in the chattel paper serve to perfect an interest in the reversion as well? The remaining pages explore this question as it affects both subsequent creditors and

82 This analysis reflects the normal contract price less market price measure of contract damages. See, e.g., E. Farnsworth, ConTracts $\$ \S 12.8-12.11$, at 838-58 (1982). If there has been no shift in the market price, Industrial can always re-lease the goods. Whether Industrial would then be entitled to damages would depend on whether Industrial was a lostvolume lessor. See Goetz \& Scott, Measuring Seller's Damages: The Lost-Profits Puzzle, 31 StAn. L. Rev. 323, 330-54 (1979) (developing an economic model for assessing lost-volume damages in excess of the contract-market price differential).

ss This analysis reflects the general rule that an injured party's recovery for breach of contract is limited by a duty to mitigate damages. See, e.g., E. FARNSwORTH, supra note 82, $\S 12.12$, at 858-68.

st The precise scope of what is covered by the term "reversion" is explored infra notes 124-49 and accompanying text.

ss The failure systematically to perceive this tie flaws Professor Boss's otherwise careful analysis. See Boss, supra note 45 , at 87 ("Conceptually and functionally, the assignment of a true lease resembles an account far more than it resembles chattel paper . . . . From the viewpoint of the assignee, the true lease and the pure or unconditional installment sale contract are virtually identical in that they both evidence the right to the payment of money, which is transferred to the assignee .... By content, the transfer of a security lease transfers not only the monetary obligation but the security as well."); see also id. ("Like the assignment of an installment sales contract, the assignment of a true lease transfers an unsecured right to payment."). Professor Boss later appears to recognize this tie, in discussing returned goods, id. at 98-99.

se The parties in the Leasing Consultants case did intend to create a security interest in the lease and in the reversionary right. Citibank took a security interest in "the lease(s) and the property leased." 486 F.2d at 369. 
existing inventory financers of Industrial.

a. Chattel paper, embodiment, and the rights of subsequent creditors. Consider first the perspective of subsequent property claimants who wish to take a security interest in Industrial's goods. The inquiry has two parts. As we have already seen, while the goods are in the hands of Industrial, the principle of ostensible ownership suggests that chattel paper should not continue to embody rights in the goods, whether the rights asserted to be embodied are those derived from Industrial's security interest, lease, or reversion. ${ }^{87}$ In that event, chattel paper's negotiability is fundamentally at odds with Article 9's baseline principle of obviating ostensible ownership of goods by making security interests in goods discoverable by possession or defined files. ${ }^{88}$

Can this result be extracted from Article 9? Section 9-306(5) will provide no direct assistance, for that section applies only to the sale of goods, ${ }^{89}$ and it seems reasonably certain that in the case of a true lease of goods, there will usually be no basis for concluding that there has been a sale. ${ }^{90}$ Despite that, however, it seems that the definition of chattel paper itself can be used to provide much the same result. A security interest in chattel paper should embody a right to goods only so long as that chattel paper is in force. It requires no great stretch of one's imagination, legal or otherwise, to conclude that after a repossession by the lessor following a default under a true lease, the lease is effectively terminated. ${ }^{91}$ In that event, there seems to be no reason to conclude, even without the direct assistance of section 9-306(5), that a security interest in the chattel paper no longer provides a security interest in the underlying goods that is effective against other property claimants of the debtor.

So long as the goods remain in the hands of Manufacturer,

${ }^{87}$ See supra notes 49-55 and accompanying text.

s Cf. Truck, Tractor \& Forwarding Co. v. Baker, $281 \mathrm{~Pa} .145,148-49$, 126 A.2d 239, 240-41 (1924) (assignee's failure to perfect interest in returned goods is a secret lien and hence fraudulent).

so Section 9-306(5) begins with the following language: "If a sale of goods results in an account or chattel paper which is transferred by the seller to a secured party, and if the goods are returned to or repossessed by the seller or the secured party, the following rules determine priorities...."

${ }^{20}$ Section 2-106(1) states that a " 'sale' consists in the passing of title from the seller to the buyer for a price (Section 2-401)." See Weisbart \& Co. v. First Nat'1 Bank, 568 F.2d 391, 394-96 (5th Cir. 1978); Chrysler Corp. v. Adamatic, Inc., 59 Wis. 2d 219, 238-39, 208 N.W.2d 97, 106 (1973).

92 Section 9-105(b), that is to say, should be read to refer to a writing that "evidences" a "lease of specific goods" only when the lease has not been terminated by repossession. 
however, the inquiry is distinct. It was earlier suggested that chattel paper embodies, during the term of Manufacturer's possession of the drill presses, Industrial's security interest in, or rights during the term of the lease to, those drill presses because these rights constituted a part of the intangible payment obligation that chattel paper exists to paperize. ${ }^{92}$ The question remaining is whether Industrial's rights to get the goods back when the lease terminates for reasons other than a breach by Manufacturer-the reversion-should also be considered embodied in the chattel paper while Manufacturer is in possession of the goods.

A conclusion that reversionary rights to goods are also embodied in chattel paper means that subsequent secured claimants of Industrial need to assume that goods not in Industrial's hands are unavailable as collateral unless Industrial is able to show them the unlegended original of the chattel paper. ${ }^{93}$ The opposite conclusion, on the other hand, would mean that a chattel-paper financer of Industrial who also wished to take a security interest in all of Industrial's rights in those goods, and not just the rights ancillary to the payment obligation under the lease, would either have to file against the goods where the goods are located or otherwise perfect an interest in those goods, ${ }^{94}$ in addition to perfecting against the chattel paper. Subsequent creditors, in that event, would, at a minimum, have to check the files in the jurisdiction where the goods were located in order to ascertain the existence of any such interests. Such creditors, as we explore below, might also have to check with the lessee.

Here, as in many other places in commercial law, it may be more important to have a rule that is clear and precise rather than standards that are imprecise and subject to litigation..$^{95}$ The problem with the approach of Leasing Consultants is not that a nonembodiment rule is necessarily worse than an embodiment rule, but that the choice of rule hinges upon the form of the underlying transaction. The Leasing Consultants analysis requires one to dis-

92 See supra notes $82-85$ and accompanying text.

93 A lease that does not state that it is subject to a security interest will allow a party, by taking possession of the lease, to assume the negotiability protections of section 9-308, see § 9-308 \& comments 2-3.

* It would be possible to file where Industrial normally possessed the goods, if the goods were thereafter not in another jurisdiction (in the hands of Manufacturer or anyone else) for more than four months. See $\$ 9-103(1)(d)$.

os See, e.g., Baird \& Jackson, supra note 4, at 206-07; Baird \& Weisberg, Rules, Standards, and the Battle of the Forms: A Reassessment of $\S 2-207,68$ VA. L. REv. 1217, 122731 (1982). 
tinguish between "true" and "security" leases, an inquiry that is either fact-specific and messy ${ }^{98}$ or governed by arbitrary rules that bear little relation to the economic distinctions between the transactions. ${ }^{97}$

Moreover, Leasing Consultants leaves open the question of what to do in the case of a "security lease" where there is a "reversion," not because of a default, but because, contrary to the "security lease" label, there has been a decision by the "lessee" either to exercise an option to cancel or not to exercise an option to purchase. ${ }^{98}$ These cases can perhaps be handled within the Leasing Consultants framework by application of section 9-306(5), but that section applies only when there has been a "sale of goods." It is by no means certain that all transactions that are deemed to be "security leases" for purposes of section 1-201(37) ${ }^{100}$ will also be

${ }^{96}$ See, e.g., In re Marhoefer Packing Co., 674 F.2d 1139, 1143-45 (7th Cir. 1982) (rejecting a rule-oriented test under $\$ 1-201(37)$ for determining whether a lease is intended for security and concluding that a characterization depends upon the court's assessment of the particular facts); Coogan, Leases of Equipment and Some Other Unconventional Security Devices: An Analysis of UCC Section 1-201(37) and Article 9, 1973 Duke L.J. 909, 934-35 (reading the language of $\S 1-201$ (37) as requiring a factual inquiry to determine whether a lease is "true" or intended for security).

${ }^{97}$ See, e.g., Aoki v. Shepherd Mach. Co. (In re J.A. Thompson \& Son), 665 F.2d 941, 946-47 (9th Cir. 1982) (construing CAL. CoM. Code $\$ 1201(37)$ (West Supp. 1982), the court concluded that "if a lease contains an option to purchase "for no additional consideration or for nominal consideration,' it is conclusively presumed to be 'intended as security,' without reference to other facts from which the opposite inference might be drawn," including options to cancel); Peco, Inc. v. Hartbauer Tool \& Die Co., 262 Or. 573, 575, 500 P.2d 708, 709 (1972) (concluding that an option to purchase for nominal consideration alone indicates that the lease is intended for security). See also In re Wright Homes, Inc., 279 F. Supp. 598 (M.D.N.C. 1968) (a case decided under pre-Code law holding that no option to purchase means that the lease cannot be a security lease, even though annual option to renew at nominal price existed for life of machinery).

${ }^{28}$ For example, under the approach of cases such as Aoki v. Shepherd Mach. Co. (In re J.A. Thompson \& Son), 655 F.2d 941 (9th Cir. 1982), transactions cast in the form of a lease may be deemed a "security lease" by virtue of a nominal option to purchase at the end of the lease, even though there is a substantial possibility that the lease will be terminated before then through means other than default. Such a result might occur, for example, if the lease were a month-to-month lease, with an option to renew each month. Furniture rentals are sometimes structured this way, often giving the lessee an option to acquire the furniture outright for little or no additional consideration after two to three years of such leasing. Most furniture rental lessees, however, never renew the leases for the duration necessary to activate the "bargain" option to purchase. When the furniture store takes the furniture back at the end of the lease, it does so as owner, not as a secured party exercising a right of default under part 5 of Article 9.

oo See supra note 89.

100 Section 1-201(37) provides:

Whether a lease is intended as security is to be determined by the facts of each case; however, (a) the inclusion of an option to purchase does not of itself make the lease one intended for security, and (b) an agreement that upon compliance with the terms of 
deemed to be "sales" by the distinct requirements for finding a "sale of goods." "101

It is, of course, easier to see that a single rule would be preferable to the two rules of Leasing Consultants than it is to pick the superior rule. That choice should be based on the relative costs and advantages of the various rules, a matter on which we can ultimately only speculate. But this speculation can start from a reasonably firm baseline. If all chattel-paper financers were really financers only on the accounts receivable of a debtor, ${ }^{102}$ and if other secured creditors-those who financed on goods-actually sought security interests in a debtor's nonpossessory reversionary rights, the nonembodiment rule would be clearly preferable.

The accuracy of this conclusion can be ascertained by examining the effects of a rule that, as to third parties, treated chattel paper as embodying reversionary rights in goods. Such a rule would create a situation in which subsequent secured creditors of Industrial wishing to take a security interest in the reversion would have to negotiate with Bank. ${ }^{103}$ As a consequence, even though Bank was not asserting an interest in the reversion, Bank would be in a position to block other creditors from loaning money to Industrial on a first priority basis. Subsequent creditors would either have to negotiate with Bank for Bank's subordination or raise their interest rates against Industrial.

In either event, Bank would acquire a "blocking" power that would enable it to garner a premium later for its agreement to subordinate. Although this would be advantageous to Bank, it would be disadvantageous to Industrial, since it would raise the cost of future credit above what it would be in the absence of Bank's potential interest in the reversion. If Bank is not likely to be a lender on such reversionary rights, moreover, the efficiency advantages of the rule to Bank will be small or nonexistent, and,

the lease the lessee shall become or has the option to become the owner of the property for no additional consideration or for a nominal consideration does make the lease one intended for security.

101 See $\$ 2-106(1)$, quoted supra note 90 . The interpretation of what constitutes a "sale" for purposes of Article 9 remains sufficiently open to accommodate variation. See, e.g., Weisbart \& Co. v. First Nat'l Bank, 568 F.2d 391, 394-96 (5th Cir. 1978) (indicating the variety of factors bearing on a determination of whether a given transaction is a sale for purposes of section 9-306(2)).

102 See supra notes 28-34 and accompanying text.

${ }^{103}$ Cf. Jackson \& Kronman, supra note 13, at 1164-82, for an exploration of a similar blocking power (there called a "situational monopoly") in the context of after-acquired property clauses and the suggestion that this power may justify the existence of a purchase money priority. 
therefore, Bank and Industrial would normally want to contract around a rule that includes the reversion in chattel paper. ${ }^{104}$ In the case of possessory interests: in the chattel paper, however, such a contractual arrangement of priorities may be difficult to publicize effectively.

A legal rule that removed this blocking power by providing that chattel paper does not embody the reversion, would, under the assumptions made, seem preferable to a rule mandating embodiment, because it would be consistent with the contractual arrangement between Bank and Industrial in the majority of cases. ${ }^{105}$ Yet such a justification for a nonembodiment rule depends on its underlying premises: that chattel-paper financing is really a form of accounts-receivable financing and that creditors want to finance on a debtor's nonpossessory reversionary rights. A substantial portion of chattel-paper financing, however, arises out of "leveraged lease" and associated transactions, in which the debtor is essentially a nominal titleholder who borrows money from lenders to acquire equipment from a supplier, which equipment is then leased out to lessees. ${ }^{108}$ In these situations, because of the debtor's nominal nature, the lenders look virtually exclusively to the lessee, and

${ }^{104}$ Cf. id. at 1172-73 (suggesting that in the absence of a rule, parties faced with the blocking power of an after-acquired property clause will seek a contract provision giving later lenders purchase money priority).

${ }^{105}$ A rule providing that chattel paper does not embody the reversion reflects the fact that in its absence parties will seek the same result by contract. Plainly, such a rule also suggests that, as a matter of contractual intent between the debtor and a chattel-paper financer, an assignment of "chattel paper" should, for purposes of interpreting the security agreement - that is to say, for purposes of interpreting whether Bank has a security interest in the collateral at all (which is part of the essentially contractual, two-party inquiry of what Industrial and Bank intended, as opposed to the essentially third-party oriented inquiry connected with issues of perfection)-be considered as assigning only the "account receivable" arising from the lease together with the ancillary contingent right of Industrial to use the property for the duration of the lease to "secure" the face amount of that account receivable. The 1952 draft of Article 9 essentially defines chattel paper in terms that incorporate such an expected contractual arrangement between the parties: " Chattel paper' means a security agreement or lease of a type which is in ordinary course of business transferred by delivery with appropriate indorsement or assignment." U.C.C. \$ 9-105(1)(b) (1952). This rule, of course, accommodates well the preceding analysis of the contractual intent underlying a nonembodiment rule. The preceding analysis of the parties' intent is also consistent with the result reached under pre-Code law. See, e.g., United States v. Shafto, 246 F.2d 338, 341-42 (4th Cir. 1957); Vadner v. Rozzelle, 88 Utah 162, 166-67, 45 P.2d 561, 563 (1935); Boss, supra note 45; see also Clark, supra note 62, at 237-38 (rule providing that the chattel paper does not embody the reversion has a "metaphysical" appeal); Levie, supra note 2, at 940-41 (arguing that the purchaser of a lease takes only an assignor's interest in the lease); see generally RESTATEMENT OF PrOPERTY §§ 154-155 (1936) (discussing reversions and powers of termination).

${ }^{108}$ For a description of leveraged leasing, see Fritch \& Shrank, Leveraged Leasing, in Equipment Leasing-Leveraged Leasing 211 (B. Fritch \& A. Reisman eds. 2d ed. 1980). 
ultimately to the equipment, for repayment. ${ }^{107}$

In this not insignificant category of cases, it is incorrect to assume that the chattel-paper financers are simply financing on the debtor's accounts receivable. They care both about the solvency of the lessee and about the value of the equipment, both during the term of the lease and, if the lease is for less than the life of the equipment, thereafter. Nonetheless, nothing in the concept of chattel paper calls for an embodiment of the reversionary right while the goods are in the lessee's hands, instead of the debtor's. Chattel paper exists to create the possessory-based advantages of negotiability that come from paperizing an intangible, an account receivable. Nothing we have yet seen suggests chattel paper also exists to capture advantages associated with paperizing a right to tangible property such as goods, except insofar as those rights are inherently ancillary to the intangible rights being paperized. ${ }^{108}$

This is not to say that Article 9 could not have decided to paperize all rights to goods that are in the hands of a buyer or lessee of a debtor. On occasion, Article 9 paperizes a right to goods, as it does when goods are held by a warehouseman who has issued a negotiable warehouse receipt. ${ }^{109}$ But in those cases, control of the goods is "locked up" in the paper as a matter of custom and procedure independent of Article 9.110 No such custom to "lock up" goods in chattel paper exists, and paperizing such rights without an independent reason probably would not be worthwhile, given the potential for "blocking" effects and other costs.

Consider the following consequences of such embodiment. Rights in goods that were leased out for a short period, such as a week or a month, would be paperized only during the lease term, but not before or after, for the reasons we previously explored.11 This transient paperizing of a reversionary right would carry substantial costs and few gains. ${ }^{112}$ It would, of course, be possible to consider perfecting an interest in chattel paper as an alternative

107 Id. at 219.

103 See supra notes 82-85 and accompanying text.

102 See $\$ 9-304(2)$. Comment 2 to section 9-304 states that subsection (2) reflects "the position that, so long as a negotiable document covering goods is outstanding, title to the goods is, so to say, locked up in the document and the proper way of dealing with such goods is through the document."

110 See Article 7 ("Warehouse Receipts, Bills of Lading and Other Documents of Title").

11 See supra notes 49-55, 81-86 and accompanying text.

112 For example, one apparently would have to take possession of the chattel paper in order to purchase the reversion safely. This would be especially troublesome in the case of goods covered by certificates of title. See $\$ \S 9-103(2),-302(3)(b)$. 
way of perfecting a reversionary interest in goods while the chattel paper was outstanding, but unless that was coupled with a rule giving trumping advantage to the possessor of the chattel paper, none of the normal advantages of paperizing rights would have been gained.

Although I examine the rights of prior inventory financers next, it is worth noting here that a trumping rule in favor of the perfected chattel-paper holder would make sense only if the chattel-paper financer were effectively a purchase-money lender who enabled the debtor to acquire the goods. It is true that in leveraged lease transactions the financers are often tantamount to purchasemoney lenders, who acquire purchase-money security interests in goods being acquired.113 But in these cases, the trumping should not come simply from possession of the chattel paper, but should depend on notification of prior inventory financers ${ }^{114}$-a process that requires examination of the recording files. Once that has occurred, the advantages of paperizing the rights have all but dissipated. Moreover, because of the conclusion that chattel paper does not, and should not, continue to embody rights to goods once the debtor is in possession of those goods, ${ }^{115}$ purchase-money financers will often file financing statements against the debtor covering those goods, irrespective of the embodiment rule regarding the reversion. ${ }^{116}$

If the goods constitute "goods which are mobile and which are of a type normally used in more than one jurisdiction," financing statement will be filed where the debtor is located, ${ }^{118}$ and will serve to perfect the interest of the financers in the debtor's rights to the goods, wherever the goods may be located. If, on the other hand, the goods are not "mobile goods," as was the case in

11 Section 9-107(b) provides:

A security interest is a "purchase money security interest" to the extent that it is . . . (b) taken by a person who by making advances or incurring an obligation gives value to enable the debtor to acquire rights in or the use of collateral if such value is in fact so used.

${ }_{134}$ See § 9-312(3); see generally Baird \& Jackson, supra note 4, at 195 ("the ability of a particular 'favored' subsequent claimant to take priority over an earlier secured party should turn . . . on the subsequent claimant's curing the ostensible ownership problem that his interest may create for the earlier secured party").

${ }^{115}$ See supra notes 49-55 and accompanying text.

${ }^{116}$ See, e.g., Reisman, Assignment of Equipment Leases by Sale or as Collateral, in Equipment LeAsing-LeVERAGEd Leasing, supra note 102, at 883, 916-17 (discussing the necessity of a filing covering the goods if a lender with a security interest in chattel paper seeks also to claim a security interest in returned or repossessed goods).

117 \& 9-103(3).

118 Id. 
Leasing Consultants, it is conceivable that the filing by the financers will not perfect their interest in the debtor's reversion while the goods are on lease in a state other than the state in which the filing was made. ${ }^{118}$

But even in that case, the choice may not be between embodiment of the reversionary rights in the chattel paper and multiple filings. Section 9-304(3) provides that "[a] security interest in goods in the possession of a bailee" can be perfected "by the bailee's receipt of notification of the secured party's interest,"120 and such perfection is, under section 9-305, tantamount to perfection by the secured party. ${ }^{121}$ Nothing in Article 9 prevents lessees in leveraged leasing or similar deals from constituting such bailees, ${ }^{122}$ and they can become bailees with notice simply by having the financer's interest noted on the lease itself. This approach, unlike an approach that embodies reversionary rights in chattel paper, provides an easy mechanism whereby chattel paper financers can choose, if it suits their needs, to take security interests in the

11 In that event, the filing needs to be made in the jurisdiction where the goods are located. $\$ 9-103(1)$. A filing made in the jurisdiction where the debtor keeps the goods will not serve to perfect (beyond the protections of the four-month reperfection rule of section 9 $103(1)(d))$ the interest in such goods when they are leased to a lessee who used them in another jurisdiction. Section 9-103(1)(c) may require the filing to be made where the lessee will use the goods if, in the leveraged leasing deal, the goods will go directly from the manufacturer to the lessee. Whether it will depends on the understanding of the debtor and the financers at the time the security interest "attaches." The rules governing attachment appear in section 9-203.

120 \& 9-304(3).

121 Section 9-305 provides that the secured party is deemed to have possession of the goods for purposes of perfection "from the time the bailee receives notification of the secured party's interest." See Looney v. Nuss (In re Miller), 545 F.2d 916, 918-19 (5th Cir.) (under sections 9-304(3) and 9-305 possession by a bailee coupled with notification of the secured party's interest was sufficient to perfect a security interest in certain paintings and sculptures), cert. denied, 430 U.S. 987 (1977). The test of whether a person holding goods is a bailee for purposes of sections 9-304(3) and 9-305 is whether his possession serves "to provide notice to prospective third party creditors that the debtor no longer has unfettered use of [his] collateral." In re Copeland, 391 F. Supp. 134, 151 (D. Del. 1975), aff'd, 531 F.2d 1195 (3d Cir. 1976). See also Ingersoll-Rand Fin. Corp. v. Nunley, 671 F.2d 842, 845 (4th Cir. 1982) (possession by bailee gave adequate notice that debtor no longer had "unfettered" use of mining equipment, thus satisfying the requirements of § 9-305); Heinicke Instruments Co. v. Republic Corp., 543 F.2d 700, 703 (9th Cir. 1976) (possession of stock certificate insufficient to indicate that stock was "fettered" and so insufficient to constitute a bailment for purposes of $\$ 9-305$ ).

${ }^{122}$ A recent bankruptcy case has suggested that one secured party cannot act as bailee for another, Hale v. Kontaratos (In re Kontaratos), 10 Bankr. 956 (Bankr. D. Me. 1981). This, however, runs contrary to pre-Code law, see Schram v. Sage, 46 F. Supp. 381, 388 (E.D. Mich. 1942), and the views of Professor Gilmore, see 1 G. GiLmore, supra note 4, \& 14.2, at 440-41. See generally DeKoven, Secured Transactions, 38 Bus. Law. 1195, 1212-14 (1983). 
reversion, externalized from the debtor, ascertainable by third parties, and without creating the blocking power that an embodiment rule creates in cases in which the chattel-paper financer is essentially an accounts-receivable financer. ${ }^{123}$

b. Chattel-paper financers and prior inventory financers. To this point, we have been examining the rights of a chattel-paper financer against subsequent secured creditors claiming an interest in the goods through the debtor. This leaves, however, one important category of embodiment conflicts. What are the rights of a chattel-paper financer to goods "covered" by the chattel paper when the conflict is with a prior secured party with a security interest in, say, the inventory of a debtor such as Industrial?

If one starts with the assumption that chattel paper does not embody reversionary rights in goods, the analysis with respect to these rights is fundamentally one of interpreting Article 9's general first-in-time rule. ${ }^{124}$ The more troublesome inquiry is the conflict that can arise over those rights in goods that are embodied in chattel paper.

Consider the following transaction. A bank, Savings, loans Industrial money, taking and perfecting by a proper filing a security interest in Industrial's "inventory wherever located, including after-acquired." When Industrial sells items from this inventory to Manufacturer, in a transaction that creates chattel paper, Savings's direct interest in those items is likely to be cut off after Manufacturer takes possession of the goods. ${ }^{125}$ But, under section 9-306(2), Savings's interest will shift automatically to the "proceeds" of this sale, which presumably means the chattel paper, ${ }^{126}$ and, under section 9-306(3), this interest in the chattel paper as proceeds will remain perfected for ten days and, even if Savings does nothing, for longer if Industrial's inventory prior to sale was located in the same jurisdiction as Industrial's chief executive

${ }^{233}$ For an argument that "direct notification or payment directly from the account debtor to the chattel-paper lender, protects the latter's interest by reducing the opportunities for collusion between the debtor and the account debtor," see Levie, supra note 2, at 937.

124 § 9-312(5).

125 Section 9-307(1) provides that "[a] buyer in ordinary course of business . . . takes free of a security interest created by his seller even though the security interest is perfected and even though the buyer knows of its existence."

${ }^{128}$ Section 9-306(2) provides that "a security interest . . . continues in any identifiable proceeds." Section 9-203(3) provides that "[u]nless otherwise agreed a security agreement gives the secured party the rights to proceeds provided by Section 9-306." The 1972 revisions to both these sections were designed to make it clear that this right to proceeds is automatic. U.C.C. $\S \S 9-306,-203$ reasons for 1972 change (1972). 
offices. ${ }^{127}$

When Industrial uses the resulting chattel paper as collateral in a subsequent transaction with Bank, the issue is joined: who prevails as to the rights to goods that become embodied in the chattel paper? The results articulated by Article 9 reflect the primacy of possession associated with negotiability. In a possessory chattel-paper transaction, Bank will prevail over Savings, whether or not Bank knows of Savings's interest, if Bank can show that it "gives new value and takes possession of [the chattel paper] in the ordinary course of [Bank's] business,"128 since, under section 9308(b), Savings is claiming the chattel paper "merely as proceeds of inventory subject to a security interest."129 If Bank is not acquiring the chattel paper for new value, but as security for an antecedent debt (for example, if Bank is a financer on Industrial's accounts receivable, however arising), or if Bank is relying on a chattel paper filing, and not possession, Savings or Bank will prevail in a priority dispute depending on who was the first to file or perfect. ${ }^{130}$ And if Savings had taken a security interest in "inventory and chattel paper," then whether Bank could prevail over Savings by taking possession of the chattel paper would depend on whether Bank, at the time of giving new value and taking possession of the chattel paper, acted "without knowledge that the specific paper or instrument is subject to a security interest." ${ }^{\text {131 }}$ Since

127 Section 9-306(3) states that the "security interests in proceeds is a continuously perfected security interest if the interest in the original collateral was perfected," but provides further that this continuously perfected interest lasts for only 10 days after receipt of the proceeds by the debtor unless inter alia (and of relevance here), " $a$ filed financing statement covers the original collateral and the proceeds are collateral in which a security interest may be perfected by filing in the office or offices where the financing statement has been filed." One files with respect to "ordinary" goods where the goods are located, § 9-103(1), and one files with respect to chattel paper where the debtor is located, $\$ 9-103(4)$ (incorporating $\S 9$ 103(3) by reference). Section 9-103(3)(d) provides that a "debtor shall be deemed located at his place of business if he has one, at his chief executive office if he has more than one place of business, otherwise at his residence."

128 § 9-308.

199 § 9-308(b). Professors White and Summers have justified this result on the ground that the chattel paper is "merely the frosting on the cake for the mere proceeds claimant." J. WhITE \& R. SUmmers, supra note $43, \S 25-17$, at 1080 . A different rationale will be developed in the following pages of this article.

130 Section 9-308 will not govern this dispute, since its preconditions have not been met. The dispute between Savings and Bank thus falls under section 9-312(5), Article 9's residual priority rule. See also § 9-312(6) (providing that the date of filing as to collateral is the date of filing as to proceeds). For additional discussion of the priority rule governing a situation such as the one described in text, see Clark, supra note 3, at 463-64, 470-72; Levie, supra note 2, at 961-62.

131 § 9-308(a). 
Bank would not have knowledge that any specific chattel paper was in fact subject to a security interest of Savings if all Bank had seen were Savings's financing statement, ${ }^{132}$ Bank would, under these facts, continue to prevail over Savings.

If Manufacturer were to default, and Industrial were to repossess the goods under its security interest, Savings's interest in the goods would reattach under section 9-306(5), ${ }^{133}$ but Bank would continue to prevail over Savings under section 9-306(5) "to the extent that the transferee of the chattel paper [Bank] was entitled to priority under Section 9-308."134

Section 9-306(5), therefore, provides a baseline rule involving the sale of goods: if the inventory financer's direct security interest in the goods is cut off by the sale to Manufacturer, then, when Industrial reacquires the goods, although the inventory financer's direct security interest in the goods "reattaches," it is subordinate to any rights of the chattel-paper financer who took priority over the inventory financer under section 9-308.

But once the goods are back in the hands of Industrial, isn't Bank's right to priority over the inventory financer, based on possession of the chattel paper, a "secret lien"? How is the inventory financer to distinguish this (returned) good from other goods of Industrial and how is it to determine whether a party such as Bank exists? Elsewhere, Professor Baird and I have suggested that, instead of engaging in a case-by-case analysis of the extent of the inventory financer's reliance on the debtor's acquisition of goods, a fixed rule may be preferable. ${ }^{135}$ Inventory financers should be notified when incoming inventory is subject to other property claims that may have priority, be they claims of purchase-money sellers, lessors, or consignors, unless such competing property interests exist for a short enough time so as to obviate the desirability of notification. ${ }^{136}$

${ }_{132}$ Unless the financing statement specifically mentioned particular chattel paper, all the financing statement would reveal was that Savings claimed, or might claim, a security interest in "chattel paper." See $\$ 9-402$ (1) (a financing statement need only indicate the "types" of collateral it covers). Such general knowledge of a potential interest in chattel paper would not seem to satisfy the more particularized requirement of section 9-308(a).

133 § 9-306(5)(a); see General Elec. Credit Corp. v. McCoy (In re Frontier Mobile Home Sales, Inc.), 635 F.2d 726 (8th Cir. 1980) (holding that a security interest in inventory reattaches to repossessed goods under $\$ 9-306(5)(a))$.

1st § 9-306(5)(b). "[T]o the extent" should mean not just "if," but should also, consistent with the contours of embodiment in chattel paper, reflect the limited embodiment of rights to goods in the chattel paper. See infra notes 139-48 and accompanying text.

195 Baird \& Jackson, supra note 4, at 206-09.

1s8 Such a short-term interest, for example, may be the reclamation right of sellers 
The same principle applies here. Bank should be able to assert a priority in the reacquired goods based on its possession of the chattel paper only if, at some time before or shortly after the reacquisition of goods, Bank has notified Savings, the inventory financer, that it is, or may be, taking a security interest in chattel paper. ${ }^{137}$

What occurs, however, if the transaction between Industrial and Manufacturer was a lease, and not a sale? In that case, some authority suggests that Savings does not have a security interest in the chattel paper as "proceeds" of Savings's security interest in inventory, on the ground that a true lease of goods is not a "sale, exchange, collection or other disposition of collateral."138 This means that Bank would defeat Savings with respect to the stream of rental payments from Manufacturer to Industrial under the lease, whether or not Bank met the requirements of section 9308. ${ }^{139}$ But there is no particular reason why an inventory financer should not be able to assert $a$ security interest in the partial disposition represented by a lease. Such a result avoids, in the first instance at least, distinguishing between "sales" and "leases." Moreover, the issue here, as is usually the case in secured transactions, is less whether Savings should enjoy a security interest than whether that interest should (a) remain perfected and (b) remain prior to the claim of other parties. ${ }^{140}$ A system that gave Savings a security interest in the lease as a "proceed" of at least a part of Savings's rights in the goods could handle both of these issues: the first, by application of section $9-306(3) ;^{141}$ the second, by application of the priority rules of section $9-308 . .^{142}$

under sections 2-507, -702. For a discussion of the seller's reclamation right in connection with the problems of ostensible ownership, see Baird \& Jackson, supra note 4, at 206-09.

132 Section 9-312(3) requires the holder of the purchase-money security interest seeking priority over a conflicting security interest in inventory to provide notice before the debtor receives the goods. Other rules (such as reperfection rules, see § 9-103(1)(d), or the rights of reclaiming sellers, see supra note 136) perhaps suggest that Industrial should enjoy a reasonable grace period.

${ }^{13 s}$ § 9-306(1). See General Elec. Credit Corp. v. Cleary Bros. Constr. Co., 9 Bankr. 40, 41 (Bankr. S.D. Fla. 1980) ("[t]he words 'otherwise disposed of' related to a permanent or final conversion, not a temporary use").

130 If Savings had taken only a security interest in inventory, and if section 9-306(2), providing that " $a$ security interest continues in collateral notwithstanding sale, exchange, or other disposition," is not applicable, Savings would not even have a security interest, much less a perfected one, in the stream of rental payments.

${ }_{140}$ See supra notes $44-47$ and accompanying text.

141 Section 9-306 (3) establishes the circumstances in which a perfected security interest in proceeds continues from a perfected security interest in the original collateral.

${ }^{142}$ Section 9-308 delineates the circumstances in which a purchaser of chattel paper 
In either event, what would be Bank's and Savings's respective rights to the leased goods? With respect to the reversion, as we have seen, ${ }^{143}$ the answer is relatively straightforward: even assuming Bank wishes to claim a security interest in that reversion, it is not embodied in the chattel paper, and the general first-to-file-orperfect rule of Article 9 therefore should continue to apply. The answer, however, is different with respect to the lessor's rights to the goods during the term of the lease. This right is ancillary to the right to the stream of rental payments-it is what buttresses the value of Manufacturer's promise to pay rentals. As such, it is tied to the "account receivable" arising out of the lease. ${ }^{144}$ If Savings has no claim to that account, as common wisdom suggests, Savings should have no claim to the ancillary right to use the property during the term of the lease. ${ }^{145}$ And if Savings enjoys-as I have argued it should-a security interest in the lease, whether Bank or Savings prevails depends on whether Bank meets the requirements of section 9-308.

No matter what the resolution of this priority dispute might be while Manufacturer is in possession of the goods under lease from Industrial, when Industrial reacquires the leased goods following a default by Manufacturer, there is no reason not to apply the analysis that we have used with respect to sales. ${ }^{146}$ Upon reacquisition, it is conceptually possible to view Savings's interest (whether or not in existence the moment before) as reattaching, since Savings retained an interest in the reversion, which is now merged with the other rights of Industrial, and the goods henceforth become inventory of Industrial's again. Vis-a-vis Bank, however, the status of Savings's rights should depend on whether Bank complied with the notification requirements discussed above with respect to sales. ${ }^{147}$ If Bank gives such notice, and assuming that Bank could have prevailed against Savings with respect to Industrial's rights to the goods while the goods were with Manufacturer pursuant to the lease, Bank should continue to prevail notwithstanding reacquisition of the goods by Industrial.

takes priority over a conflicting security interest in the proceeds of inventory.

143 See supra notes 102-23 and accompanying text.

14 See supra notes 9-30, 81 and accompanying text.

145 The "term of the lease" should be defined to encompass only the mandatory remaining term. Should Manufacturer have had options to renew, for example, failure to exercise these options would have amounted to a nondefault termination of the lease, and hence a reacquisition under the reversion. See infra note 148 and accompanying text.

${ }^{146}$ See supra notes 133-37 and accompanying text.

167 See supra notes $135-36$ and accompanying text. 
This leaves one troublesome case: the termination of the transaction between Industrial and Manufacturer, not through breach, but by consent, either ex post (the parties mutually agree to terminate the deal) or ex ante (as when Manufacturer has negotiated an option to cancel). Consider the case where Industrial sells goods to Manufacturer on installment and then, when Manufacturer has payment difficulties, Manufacturer and Industrial agree to allow Industrial to retake the goods (and title thereto) in exchange for the cancellation of Manufacturer's payment obligation. When Industrial repossesses the goods, what, if any, rights does Bank continue to have? Is Industrial's right to repossess the goods under these circumstances a reversionary-type right, not embodied in the chattel paper, or is this a right "ancillary" to the payment obligation?

Since this consensual repossession is functionally equivalent to a reacquisition and retention following default under section 9$505,{ }^{148}$ there appears to be little reason not to conclude that the right is ancillary to the lease and embodied in the chattel paper. Industrial, to avoid the expense and hassle of litigation, exchanges its rights to repossess the goods and to sue Manufacturer for any deficiency, for the release by each side of its rights against the other. This exchange should not change the nature of the embodied interests: the chattel paper should continue to embody Industrial's right to the goods. ${ }^{149}$ But upon reacquisition of the goods by Industrial, Bank will nonetheless have to file for protection against subsequent creditors and notify Savings or other prior creditors.

Is the situation the same, however, when the transaction is terminated not by the mutual agreement of Manufacturer and Industrial at the time of termination, but by Manufacturer's exercise of a unilateral right, such as an option to cancel (or not to renew) under a lease? Manufacturer's unilateral power to terminate without breach, mutually agreed to at the time of entering the lease, is fundamentally different from the negotiated termination ex post, which requires consent of both parties. In the former case, Manufacturer's bargained-for right is a part of the value of the package negotiated; in the latter case, the termination is a substitution for rights that had previously existed and had been valued. For this reason, chattel paper's embodiment of Industrial's rights in the

148 Section 9-505(2) provides that "a secured party in possession may, after default, propose to retain the collateral in satisfaction of the obligation."

140 The example would be fundamentally the same if it were a mutual cancellation of a lease during its term, rather than the mutual cancellation of a sale. 
goods should encompass only those rights up to the time of Manufacturer's unilateral exercise of a right of cancellation. Once Manufacturer exercises that right, the chattel paper financer's right to use the goods, as ancillary to the right of payment, disappears, as does the right of payment itself.

\section{ConcLusion}

Chattel paper exists as a category of collateral because it paperizes an intangible: the account receivable. In so doing, chattel paper becomes a type of collateral with attributes of negotiability, principal among which are the role of possession and the fact that one need only examine the paper for information surrounding transfers of the collateral. In creating chattel paper, however, the concept of collateral ultimately must embody not only the intangible right, but also, to some extent, rights in tangible objects known as goods. This is so because the value of the paperized account depends on the package of rights that exists against the account debtor and his other creditors.

The role of embodiment in chattel paper of rights in goods, however, can be understood only in relation to Article 9's larger concern with establishing a system of priority and filing rules based, in the first instance, on the physical possession of tangible personal property by a debtor. ${ }^{100}$ When a debtor has such possession, Article 9 establishes-incompletely, to be sure $\mathrm{e}^{151}$ - a principle that all security interests in such goods can be disclosed very simply by a skeletal filing system. But when a debtor is not in possession of such goods, and therefore the misleading implications of ownership stemming from possession by the debtor do not arise, Article 9 places the burden on other parties to find out the status of the debtor's ownership rights in that property.

Embodiment in chattel paper of rights to tangible collateral is part and parcel of that structure. While the debtor is in possession of goods, rights to those goods should not be deemed to be embodied in any chattel paper resulting from transactions in those goods, because of the ostensible ownership problems otherwise created. There is, however, nothing fundamentally inconsistent with the principle of ostensible ownership in permitting embodiment while the goods are out of the debtor's hands. Yet whether and to what

150 The force of such a system is explored in Baird \& Jackson, supra note 4, at 179-90.

${ }^{182}$ See id. at 187-88, 197-201, 209-12, for a discussion of circumstances in which Article 9 uses an abstract concept such as "title" rather than possession to determine property rights. 
extent embodiment during the period of nonpossession should be deemed to exist depends, in the first instance, on the costs associated with placing the risks on one party rather than on another. $\mathrm{A}$ conclusion that reversionary-type rights to goods should not be embodied in chattel paper stems not so much from the possibility that embodiment will raise misleading implications, but, rather, from a sense that a contrary conclusion would sweep too broadly, requiring third parties to negotiate with a chattel paper financer while providing no associated benefits.

With respect to the rights to the goods that are ancillary to the payment right, embodiment is a necessary part of making the associated account receivable more negotiable. Such embodiment is without ostensible ownership problems, as long as it is constrained so as to apply only while the debtor is out of possession. Subsequent parties are put to finding out the relationship between the possessor and the debtor; when they learn about that relationship, they have the ability to find out whether there are prior parties who have claimed any property rights in the debtor's rights in such property. But the justification for embodiment lasts only so long as the debtor is out of possession of the collateral-a conclusion section 9-306(5) expresses somewhat incompletely and inadequately, but nonetheless clearly.

If we all were sensitive to the reasons for the existence of chattel paper as a category of collateral and to the direct relation between embodiment and the ostensible ownership principle, much of the mystique surrounding chattel paper would disappear. With such an understanding, we would, at long last, be able to handle chattel paper questions without engaging in theoretical distinctions that have no practical application. 